\title{
СРАВНЕНИЕ СЕРДЕЧНО-СОСУДИСТЫХ ИСХОДОВ У БОЛЬНЫХ САХАРНЫМ ДИАБЕТОМ 2 ТИПА, ПОЛУЧАВШИХ И НЕ ПОЛУЧАВШИХ ИНГИБИТОРЫ НАТРИЙГЛЮКОЗНОГО КО- ТРАНСПОРТЕРА 2 ТИПА (ПО ДАННЫМ МОСКОВСКОГО СЕГМЕНТА ФЕДЕРАЛЬНОГО РЕГИСТРА САХАРНОГО ДИАБЕТА С 2016 ПО 2020 ГГ.)
}

\author{
'Демидов Н.А., ${ }^{2}$ Балберова М.А., ${ }^{3}$ Анциферов М.Б. \\ 'ГБУЗ «Городская больница г. Московский Департамента здравоохранения г. Москвы» \\ гГБУз «Больница «Кузнечики» Департамента здравоохранения г. Москвы» \\ ЗГБУЗ «Эндокринологический диспансер Департамента здравоохранения г. Москвы»
}

Сердечно-сосудистые заболевания (ССЗ) являются инвалидизирующими осложнениями сахарного диабета 2 типа (СД2), ассоциированными с высоким риском смерти.

Опыт многочисленных крупномасштабных исследований последних 5 лет по применению ингибиторов натрий-глюкозного ко-транспортера 2 типа (иНГЛТ-2) говорит о возможности существенного снижения риска ССЗ.

Федеральный регистр больных сахарным диабетом (ФРСД) является базой данных, в которой учитывается смертность больных СД с указанием причины смерти, а также факт развития ССЗ.

В нашей работе, проведенной на основании данных Московского сегмента ФРСД, был проведен анализ риска сердечно-сосудистой смерти (ССС) или развития СС3 у больных СД2, получавших терапию иНГЛТ-2 с 2016 г. по сравнению с больными, которые данных препаратов не получали.

ЦЕЛЬ: изУчить относительный риск развития ССЗ и ССС при применении иНГЛТ-2 у больных СД2.

МАТЕРИАЛЫ И МЕТОДЫ: из базы данных Московского сегмента ФРСД была сформирована выборка больных СД2, получавших иНГЛТ-2 с 2016г. (Группа 1, n=611 чел.) С помощью псевдорандомизации методом подбора пар была сформирована группа больных СД2, не получавших терапию иНГЛт-2 (Группа 2, n=611 чел.) с учетом пола, возраста, длительности СД2, ИМТ, применения инсулинотерапии и анамнеза СС3.

Был проведен статистический анализ риска ССС больных СД2 и риска развития ССЗ.

PEЗУЛЬтАTЫ: в обеих группах пациентов было оценено количество и доля пациентов, умерших в течение периода наблюдения, а также количество больных, с вновь диагностированными ССЗ.

На сегодняшний момент закончен анализ данных 300 больных СД2 обеих групп. Средний возраст боль-

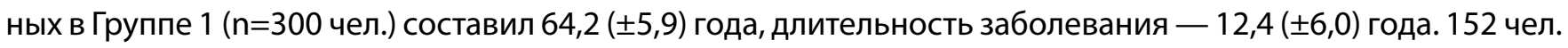
$(50,7 \%)$ находились на инсулинотерапии. Уровень НbАс1 составил 7,5\% ( $\pm 0,9 \%)$, ИМТ - 34,8 ( $\pm 5,9) \mathrm{kг} / \mathrm{M}^{2}$. Показатели у пациентов Группы 2 статистически не отличались от Группы 1.

По предварительным данным летальность в Группе 1 составила 4,0\% (12 чел.), из них сердечно сосудистая (СС) летальность - 3,0\% (9 чел.). Вновь выявленные в течение периода наблюдения ССЗ были зарегистрированы у 4 чел. (1,3\%). При этом у 2 чел. зафиксирован ИМ, и у 2 чел. - ОНМК. Таким образом, крупные СС события были зарегистрированы у 4,3\% (13 чел.).

В Группе 2 летальность составила 5,7\% (17 чел.), из них СС летальность - 4,7\% (14 чел.). ИМ зафиксирован у 4 чел. (1,3\%), ОНМК у 3 чел. (1,0\%). Таким образом, крупные СС-события зафиксированы у $8,0 \%$ (24 чел.).

Абсолютный риск СС смерти в Группе 1 составил 0,03, в Группе $2-0,047$, относительный риск - 0,643 (95\% ДИ 0,283-1,462), риск развития крупного СС-события в Группе 1 составил 0,043, а в Группе $2-0,08$, относительной риск - 0,542 (95\% ДИ 0,281-1,044).

\section{ВЫВОдЫ.}

1. Применение иНГЛ-2 у больных СД2 продемонстрировало тенденцию к снижению относительного риска СС смерти на $36 \%$, риска крупного СС-события на $46 \%$.

2. На момент проведения промежуточного анализа данных 300 пациентов показатели риска развития ССЗ или СС смерти в двух группах не имели статистически значимых различий. 